\title{
A STUDY ON RADIATION INJURY OF THE ERYTROCYTE MEMBRANE
}

\author{
Giichi YosHII \\ Department of Radiobiology, Faculty of Veterinary Medicine, \\ Hokkaido University, Sapporo
}

(Received for Publication May 27, 1972)

It is of importance to study radiation injury in biological membrane as a step to clarify the membrane mechanism of cellular death by ionizing radiation. Since the cell membrane is understood to play a prominant part in cell activity especially in higher animals, there have been many observations ${ }^{2,3,8,10)}$ made on the physicochemical changes of the membrane by ionizing radiation, such as those in the electrical properties of the cell membrane and the membrane permeability. No observations, however, seem to have been made on a systematic basis. In the present study it was attempted to obtain information systematically on the initial damage of the cell membrane caused by a relatively low dose of irradiation.

\section{MATERIALS AND METHODS}

Rat erythrocytes with a simple cell metabolism seem to be suitable materials for the study of the cell membrane. In this experiment, ${ }^{3} \mathrm{H}_{2} \mathrm{O} \beta$-rays were employed so that measurements of the dielectric constant and conductivity of erythrocyte suspension for a continuous irradiation might be made with more convenience. To $5 \mathrm{ml}$ of erythrocyte suspension was added $0.1 \mathrm{ml}{ }^{3} \mathrm{H}_{2} \mathrm{O}(1 \mathrm{Ci} / 0.1 \mathrm{ml})$, thus the concentration resulting in $200 \mathrm{mCi} / \mathrm{ml}$. The dose rate calculated was about $40 \mathrm{rads} / \mathrm{min}$.

To find out changes in permeability of the cell in a post-irradiation status, irradiation was carried out from a ${ }^{60} \mathrm{Co} \gamma$-ray source at a dose rate of $40 \mathrm{rads} / \mathrm{min}$, as determined by a Victoreen chamber. Throughout the experiment $5 \mathrm{ml}$ of each cell suspension was kept usually at $25^{\circ} \mathrm{C}$.

1. Biologically, the changes in electrical properties are of great importance, because they are generally detectable at a dose which is too small to produce any measurable chemical change but enough to produce a pronouced biological effect.

In observing changes in the cell membrane exposed to a continuous irradiation $(40 \sim 1200 \mathrm{rads})$, measurements were made of the dielectric constant and conductivity of the erythrocyte suspension with Cole's bridge 4) by using alternating current at a frequency of $4 \mathrm{Mc} / \mathrm{sec}$ and an oscilloscope. Besides, ${ }^{60} \mathrm{Co} \gamma$-rays were used in a post-irradiation
status.

2. To make the above results more clear, the erythrocyte suspension was subjected to the permeability test. As a result, changes in membrane permeability seemed to be related to the physical process of radiation injury. Erythrocytes which had been labeled with ${ }^{3} \mathrm{H}_{2} \mathrm{O}$ as a tracer were suspended in $0.9 \%$ NaCl solution and irradiated with $\gamma$-rays $\left(600 \sim 4000\right.$ rads). After irradiation, ${ }^{3} \mathrm{H}_{2} \mathrm{O}$ effluxes were measured chronologically by a liquid scintillation counter. To modify the radiation effect on the cell membrane, experiments were carried out in solutions of different osmotic pressure; that is, erythrocytes 
were suspended in 0.5 and $1.5 \% \mathrm{NaCl}$ solutions.

3. To obtain any information on the biochemical process which would affect changes in cell membrane permeability, observation was made on an difference in ${ }^{3} \mathrm{H}_{2} \mathrm{O}$ efflux rate between two temperatures, 10 and $25^{\circ} \mathrm{C}$. Morphological changes (discoid $\rightarrow$ crenated) following the irradiation (1000 and 4000 rads) were examined photomicroscopically. Inosine and adenine $(3 \mathrm{mg})$ were added to the erythrocyte suspension to observe a possible restoration to a normal shape ${ }^{9)}$.

\section{RESULTS}

1. An increase in the dielectric constant and a decrease in the conductivity of the erythrocyte suspension were observed from the beginning up to 600 rads, as shown in

Fig. 1. Dielectric Increment of Erythrocyte Suspension.

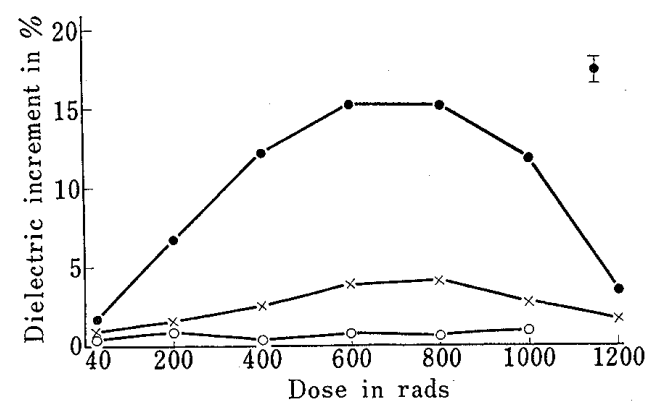

Dose rate: $40 \mathrm{rad} / \mathrm{min}$

Frequency: $4 \mathrm{Mc} / \mathrm{sec}$

$\Phi$ range of errors

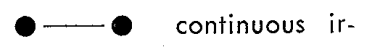

radiation $\times \longrightarrow 20$ minutes after irradiation $\mathrm{O}-\mathrm{O}$ continuous irradiation of destroyed cells
Fig. 2. Changes in Conductivity of Erythrocyte Suspension.

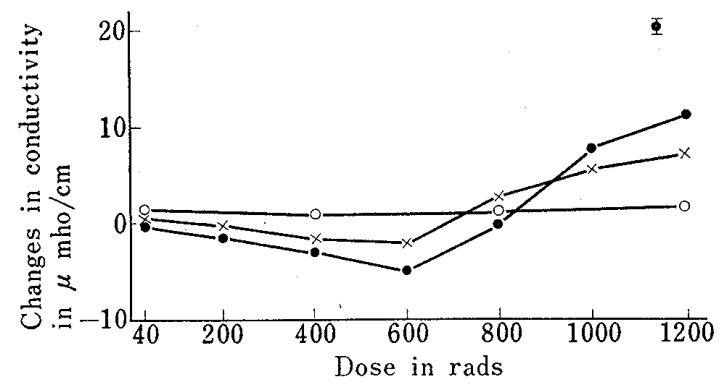

Dose rate: $40 \mathrm{rad} / \mathrm{min}$

Frequency: $4 \mathrm{Mc} / \mathrm{sec}$

range of errors confinuous ir-

radiation $\times-\times 20$ minutes after irradiation $O-O$ continuous irradiation of destroyed cells

Fig. 3. ${ }^{3} \mathrm{H}_{2} \mathrm{O}$ Efflux Rate from Erythrocytes versus Dose Given.

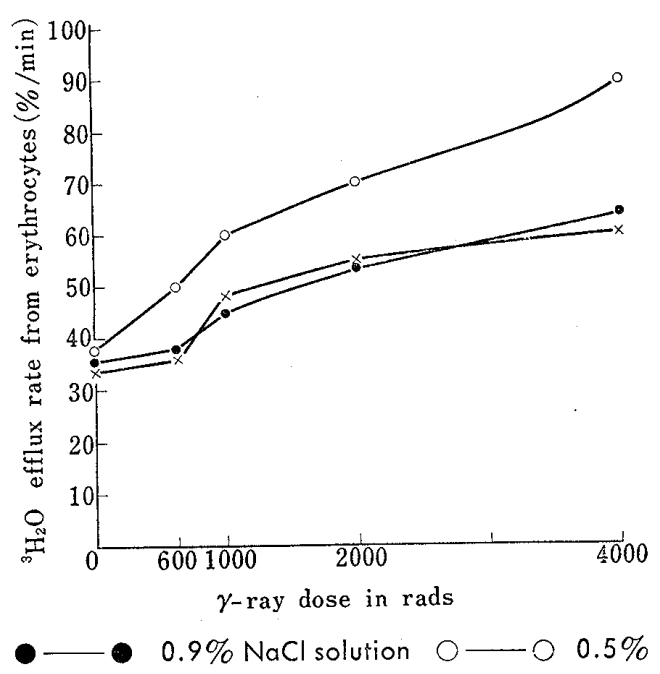

$\mathrm{NaCl}$ solution $\times \longrightarrow \times 1.5 \% \mathrm{NaCl}$ solution 
Table 1. Effect of ${ }^{60} \mathrm{Co} \gamma$-rays on ${ }^{3} \mathrm{H}_{2} \mathrm{O}$ efflux rate $(\% / \mathrm{min})$

from erythrocytes in isotonic, hypotonic, and hypertonic solutins at $25^{\circ} \mathrm{C}$

\begin{tabular}{lccccc}
\hline \multirow{2}{*}{ Solution } & \multicolumn{5}{c}{ Dose in rads } \\
\cline { 2 - 6 } & 0 & 600 & 1000 & 2000 & 4000 \\
\hline $0.9 \% \mathrm{NaCl}$ & 36 & 38 & 45 & 54 & 94 \\
$0.5 \% \mathrm{NaCl}$ & 38 & 50 & 60 & 70 & 88 \\
$1.5 \% \mathrm{NaCl}$ & 39 & 38 & 48 & 55 & 90 \\
\hline
\end{tabular}

Table 2. Effect of ${ }^{60} \mathrm{Co} \gamma$-rays on ${ }^{3} \mathrm{H}_{2} \mathrm{O}$ efflux rate $(\% / \mathrm{min})$ from erythrocytes at $25^{\circ} \mathrm{C}$ and $10^{\circ} \mathrm{C}$

\begin{tabular}{cccccc}
\hline & \multicolumn{5}{c}{ Dose in rads } \\
\cline { 2 - 6 } Temp. & 0 & 900 & 1000 & 2000 & 4000 \\
\hline $25^{\circ} \mathrm{C}$ & 36 & 38 & 45 & 54 & 64 \\
$10^{\circ} \mathrm{C}$ & 34 & 39 & 43 & 52 & 60
\end{tabular}

Figs. 1 and 2. Irradiation with more than $800 \sim 1000$ rads resulted in a decrease in the dielectric constant and an increase in the conductivity of the cell suspension. The dielectric constant and conductivity measured in a post-irradiation status underwent less changes than those measured for a continuous irradiation. This suggests that some of the changes observed for a continuous irradiation may apparently be reversible. The above findings may be interpreted as changes in ion permeability of the cell membrane ${ }^{8,9)}$.

2. The effect of ${ }^{60} \mathrm{Co} \gamma$-rays on ${ }^{3} \mathrm{H}_{2} \mathrm{O}$ efflux rate are presented in Fig. 3 and Table 1. There was no significant difference membrane permeability for ${ }^{3} \mathrm{H}_{2} \mathrm{O}$ between a sample irradiated with 600 rads and a non-irradiated sample in 0.9 or $1.5 \% \mathrm{NaCl}$ solution. In $0.5 \% \mathrm{NaCl}$ solution, however, an increase in permeability was observed in samples irradiated with 600 rads. In samples irradiated with 1000 rads even in 0.9 and $1.5 \%$ $\mathrm{NaCl}$ solutions, permeability increased and changes were enhanced in proportion to the dose given. In those in $0.5 \% \mathrm{NaCl}$ solution, the enhancement was more obvious.

3. There was a slightly greater increase in $3 \mathrm{H}_{2} \mathrm{O}$ efflux rate at $10^{\circ} \mathrm{C}$ than at $25^{\circ} \mathrm{C}$ evidently due to the difference in thermal diffusion rate, as shown in Table 2. Morphologically, erythrocytes retained their normal shape even 180 minutes after irradiation with 1000 rads. At irradiation with 4000 rads, erythrocytes failed to maintain their normal discoid shape, turning to take a crenated disk shape ${ }^{9)}$. They were regenerated by the addition of inosine and adenine.

\section{DISCUSSION AND CONCLUSIONS}

Radiation injury to the erythrocyte membrane was detected initially as change in electrical properties. Changes in dielectric constant and conductivity of the erythrocyte were observed at a continuous irradiation even with a dose of 40 rads, although some of them were reversible in the post-irradiation status (Figs. 1 and 2). It is clear that the increase in conductivity was proportional to the ion concentration of the suspension. Moreover, the decrease in dielectric constant was replaced by the decrease in conductivity, as expected from the formula given by FRICKE ${ }^{5)}$. Thus, these changes can be explained in terms of the ion movement from the outside to the inside of the cell, 
triggered by reactions between membrane molecule and ion or some free radical produced inside or outside the cell following irradiation.

After administration with a certain dose, the gradient of electrical changes proved to be inverse. The inversion occurred obviously at a dose between a low dose (600 rads) and a medium dose (1000 rads). So there must have been successive events in radiation injury of the membrane. After a certain dose, the development of ionic processes of the opposite direction was initiated. In this period, the overall electric charge in the system increased due to the liberation of a number of ions through the membrane, evidently because of the beginning of the destruction of the membrane ${ }^{11}$.

There was no significant difference in membrane permeability to ${ }^{3} \mathrm{H}_{2} \mathrm{O}$ in an isotonic solution between non-irradiated and low irradiated samples. In a hypotonic solution, however, a low dose irradiation caused an increase in membrane permeability, as shown in Fig. 3. The membrane tension produced by osmotic pressure should be considered as a direct mechanical tension. So, the author is inclined to speculate that the factor of tension may be important for the intracellular membrane under irradiation. Namely, a stress of radiation effects in a hypotonic solution is assumed to indicate that membrane permeability for ${ }^{3} \mathrm{H}_{2} \mathrm{O}$ intensively enhances changes when radiation cooperatively affects the mechanical tension of the membrane.

At irradiation with a medium dose, permeability increased even in an isotonic solution (Fig. 3). Kavanou ${ }^{7)}$ proposed that pores in the biological membrane might be in two states; that is, an open configuration and a closed configuration, and that the transformation betwen the two configurations might be related intrinsically to the membrane function. Therefore, if the radiation dose amounts to a critical one, the closed configuration will be transformed into an open one, which is assumed to be rather unstable. If this assumption is valid, the change in membrane permeability in an isotonic solution at irradiation with a medium dose will reflect a cooperativeness of radiation with the changes of the membrane state ${ }^{6)}$ in living cells.

At irradiation with a low or medium dose, no biochemical damage seemed predominant. At irradiation with a high dose, erythrocytes underwent morphological changes, with their normal shape regenerated by the addition of inosine and adenine; namely, biochemical injury became predominant.

\section{REFERENCES}

1) Bergeder, H. D. (1961): Strahlentherapie, 115, 90 104.

2) Bresciani, F., Auricchio, F. and Flore, C. (1964): Radiation Research, 21, 394 412.

3) Brinkman, R. and Lamberts, H. B. (1965): Current Topics in Radiation Research, Vol. 2, p. 281 302. North-Holland Pub. Co. Amsterdam.

4) Cole, R. H. and Gross, P. M., Jr. (1949): Rev. Sci. Instrum., 20, 252 258.

5) Fricke, H. (1926): J. Gen. Phisiol., 9, 137 147.

6) Hill, T, L. (1967): Proc. nat. Acad. Sci. 58, $111 \sim 114$.

7) Kavanou, J. L. (1965): Structure and Function in Biological Membranes, Vols. 1\& 2, Holden-Day, San Francisco.

8) Lessler, M. A. (1959): Science, 129, 1551 1552.

9) Nakao, M., Nakao, T., Yamazoe, S. and Yoshikawa, H. (1961): J. Biochem., 49, 487〜 492.

10) Stein, G., Seaman, G. V. F. and Heard, D. H. (1962): Natupe, 193, 238 239. 


\title{
赤血球膜の放射線捐傷の研究
}

\author{
吉 井義 一 \\ 北海道大学獣医学部獣医放射線学教室 \\ （昭和47年 5 月 27 日受付）
}

\begin{abstract}
放射線による間期の細胞死は, 膜に起因するこ とが多い。低線量で初期捐傷は, 膜の電気的特性 で観察される，600 rads 以下では，その変化は可 逆的であるが, $1000 \mathrm{rads}$ では, 電気的特性は一 方的に変化し, 膜からのイオン流出として帰結さ れる。 ${ }^{3} \mathrm{H}_{2} \mathrm{O}$ を用いた流出実験でも，これを裹付 ける。
\end{abstract}

膜を低張にして機械的張力を与えると，600 rads でも流出が見られる.これは正常の張力で， $1000 \mathrm{rads}$ の流出も生きてる膜のあり方が放射線 に協力的に働くことを示唆する.

$4000 \mathrm{rads}$ では, 上記の物理的捐傷は生化学的 捐㑺に進んでることが，アデニン，イノシンを用 いた実験で解明された。 